\title{
Wheat productivity in response to ridge sowing and nitrogen application on rainfed condition
}

Muhammad Ibrahim ${ }^{1}$, Jihad Ali ${ }^{1}$, Mian Ahmad Raza ${ }^{1}$, Inayat-urRahman $^{1}$, Irshad Ali Khan ${ }^{1 *}$, Sheraz Ahmad Khan ${ }^{1}$, Junaid Khan ${ }^{1}$, Abdur Rehman ${ }^{2}$ and Attaullah ${ }^{1}$

1. Department of Agriculture, The University of Swabi, KP-Pakistan

2. Directorate of Agriculture Research FATA, ARI, Tarnab-Peshawar

*Corresponding author's email: irshad_1242000@yahoo.com

Citation

Muhammad Ibrahim, Jihad Ali, Mian Ahmad Raza, Inayat-ur- Rahman, Irshad Ali Khan, Sheraz Ahmad Khan, Junaid Khan, Abdur Rehman and Attaullah. Wheat productivity in response to ridge sowing and nitrogen application on rain fed condition. Pure and Applied Biology. Vol. 8, Issue 1, pp523-529. http://dx.doi.org/10.19045/bspab.2018.700212

\begin{tabular}{llll}
\hline \hline Received: 10/09/2018 & Revised: 10/12/2018 & Accepted: 13/12/2018 & Online First: 18/12/2018 \\
\hline
\end{tabular}

\section{Abstract}

Wheat cultivation in Pakistan is carried out on more than half area in rain fed condition. To improve the average yield of country the only possible reason is to enhance productivity of wheat crop in dry areas. Current study response of wheat productivity to ridge sowing method and nitrogen levels was studied in rain fed condition at the research farm of The University of Swabi, during 2015-16. The experiment was carried out in split plot design having four replications. Sowing methods were assigned to main plot while nitrogen levels were allotted to sub plot factors. It was observed that on ridge bed sowing method tiller per meter square (256), productive tiller (216.55), thousands grains weight (46.110), biological yield (8549.1), grain yield (2429.5) and harvest index (33.50) were significantly increases over flat method. In case of nitrogen application maximum tiller per meter square (240.12 Numbers), productive tiller (240.12 Numbers), thousands grains weight $(59.70 \mathrm{~g})$, biological yield $\left(7388.7 \mathrm{~kg} \mathrm{ha}^{-1}\right)$, grain yield $\left(2396.96 \mathrm{~kg} \mathrm{ha}^{-1}\right)$ and harvest index (32.50) were recorded in plots receiving nitrogen at the rate of $120 \mathrm{~kg} \mathrm{ha}^{-1}$. Thus it is concluded that sowing of wheat on ridges produces maximum yield as compare to flat sowing and nitrogen application at the rate of $120 \mathrm{~kg} \mathrm{~N} \mathrm{ha}^{-1}$ had higher yield than rest therefore it is recommended that wheat sowing on ridges with the application of $120 \mathrm{~kg} \mathrm{~N} \mathrm{ha}^{-1}$ in rainfed areas can improve the wheat productivity in Pakistan.

Keywords: Flat sowing; Nitrogen; Productivity; Ridge; Wheat

\section{Introduction}

In current era the tremendous increase in human population need great attention towards the agriculture sector to provide satisfactory food for human needs. Wheat is used as a major staple food crop in Pakistan [1], its production is not enough to supply food to whole Pakistan population because about 80 percent arable land are come under rain fed condition where special techniques are required to carry proper agriculture practices. Sowing of wheat crop on ridges is one of technique which can improve wheat productivity by holding proper moisture, 
greater nutrients availability and good crop stand in rain fed areas. During 2015-16, the area under wheat cultivation increased to 9260 thousands hectares from last year area to 9204 thousand hectares which shows an increase of 0.6 percent, while the production of wheat was recorded stood at 25.482 million tons during 2015-16 (Pakistan economic survey (2015-16) [2].

Wheat yield varies mostly due to change in its contributing characters because yield per unit area is the product of several contributing factors including traits related to the growth attributes and number and weight of grains [3]. However wheat yield can be increased through development of productive genotypes which better adapt various agro, climate condition and also resist all types of stresses. In Khyber Pakhtunkhwa, the total area under cultivation is about 1.92 million hectares out of which 1.2 million comprises of dry land farming which is more than $60 \%$. The total area in KPK under wheat is 0.72 million hectares out of which $57 \%(0.41$ million hectares) of cultivated area is rain fed [4].

The climate of Peshawar valley is conducive to growth and production of wheat, having high-yielding varieties, ample resources, fertile land and hardworking farmers. But the growers fail to achieve the optimum potential of wheat crop. There are many constraints in raising wheat crop [5].

Wheat flat planting with flood irrigation leads to inferior water use efficiency and lower crop yield. This practice also results in greater crop lodging and enhanced frequency of crop diseases (6). It has been estimated that over $90 \%$ of the agricultural production comes from irrigated areas [7,8] describes that the bed and furrow sowing technique is an important improvement in the application efficiencies of using irrigation water.

Ridge planting method is recommended for good crop yield in rain fed area. Ridge planting method increased crop yield, reduced demand for irrigation water, reduced expenses on agricultural inputs, increased farm income, simplified farm operations increased soil moisture, improved soil cover, reduced salinity.

[9] Reported that spilt $\mathrm{N}$ application had little effect on yield, but decreased lodging and spike population, while grain weight increased. [10] Reported that spike numbers and grain weight were increased with high level of nitrogen.

Thus growing wheat crop on ridge is very useful because it demand low inputs, easier method to farmer give more production ,improved soil physical properties.

\section{Materials and methods}

An experiment entitle "Response of wheat productivity to different sowing methods and nitrogen Levels" was carried out at the research farm of The University of Swabi, Khyber Pakhtunkhwa, Pakistan in rabi 201516. The experiment was carried out in split plot arrangements having four replications. Sowing methods was assigned to main plot while nitrogen levels were allotted to sub plot factors. Land was ploughed with cultivator and ridger. The plot size of $3 \mathrm{~m} \times 5 \mathrm{~m}$ was maintained. Each plot have five rows, $5 \mathrm{~m}$ length and ridge to ridge spacing was $60 \mathrm{~cm}$. Wheat variety Pirsabak-2013 was sown at a uniformed seed rate of $100 \mathrm{~kg} \mathrm{ha}^{-1}$. Five levels of nitrogen were used. Half of nitrogen was applied at sowing time. The remaining half nitrogen was applied after four weeks of sowing. All the agronomic practices were applied uniformly throughout the experiment.

\section{Factor A: Sowing methods}

1. Ridge bed sowing

2. Flat sowing

Factor B: Nitrogen level (urea $\mathrm{kg} \mathrm{ha}^{-1}$ )

1. 100

2. 120

3. 140

4. 160

5. 200 


\section{Statistical analysis}

Data of the parameters were analyzed statistically following appropriate method using computer software Statistix 8.1. Mean were separated using least significant difference test.

\section{Results and discussion}

\section{Tiller $\mathbf{~ m}^{-2}$}

Data regarding tiller $\mathrm{m}^{-2}$ are shown in table 1 . Highest number of tillers was recorded in those plots where ridge sowing method was done (256.55). While less number of tiller was recorded in those plots where flat sowing method was done (238.40). However, in case of nitrogen application maximum number of tiller (262.37) was recorded at $200 \mathrm{~kg} \mathrm{~N}^{-1}$ followed by $160 \mathrm{~kg} \mathrm{~N}^{-1}$ (253.13) while minimum number of tiller was recorded in those plots where nitrogen was applied at the rate of $100 \mathrm{~kg} \mathrm{~N} \mathrm{ha}^{-1}$ (235.25). However, the effects of sowing methods and interaction of sowing methods and nitrogen were found significant in which the highest values was recorded in ridge sowing receiving nitrogen rate of $200 \mathrm{~kg} \mathrm{ha}^{-1}$, while the lowest number of tillers per meter square were observed in flat sowing receiving nitrogen rate of $100 \mathrm{~kg}$ $\mathrm{ha}^{-1}$. Plant tiller mainly depend on crop stand [11], root penetration [12] proper nutrients application [13]. These findings results were supported by [14] who reported that nitrogen rates significantly increase number of tillers.

\section{Productive tiller}

Data regarding productive tiller are shown in table 1. Highest number of tillers was recorded in those plots where ridge sowing method was done (256.55). Similarly less number of tiller was recorded in those plots where flat sowing method was done (238.40). However, in case of nitrogen application maximum number of tiller (262.37) was recorded at $200 \mathrm{~kg} \mathrm{~N} \mathrm{ha}^{-1}$ followed by $160 \mathrm{~kg}$ $\mathrm{N} \mathrm{ha}^{-1}$ (253.13) while minimum number of tiller was recorded in those plots where nitrogen was applied at the rate of $100 \mathrm{~kg} \mathrm{~N}$ $\mathrm{ha}^{-1}$ (235.25).Productive tiller mainly depend on soil fertility [15], proper nutrients application [16] and on the water availability [17]. However, the effects of sowing methods and interaction of sowing methods and Nitrogen were found significant in which the highest values was noted in ridge sowing receiving nitrogen rate of $200 \mathrm{~kg} \mathrm{ha}^{-1}$, while the lowest number of tillers per meter square were recorded in flat sowing receiving nitrogen rate of $100 \mathrm{~kg} \mathrm{ha}^{-1}$. These findings were supported by [14] who reported that nitrogen rates significantly increase number of tillers. [18] also show that bed sowing of wheat not only saves water but improves fertilizer use efficiency.

\section{Thousand grain weight (g)}

Data regarding thousand grain weights were shown in table 2. Highest thousand grain weight was obtained in those plots where ridge sowing method was done (64.110). While less amount of thousand grain weight were recorded in those plots where flat sowing method was done (47.185). In case of nitrogen application maximum number of thousands grains weight (60.70) were recorded at $100 \mathrm{~kg} \mathrm{~N} \mathrm{ha}^{-1}$ (60.70) followed by $120 \mathrm{~kg} \mathrm{~N} \mathrm{ha}^{-1}$ (59.70). Similarly minimum amount of thousand grain weight (49.18) were recorded at $200 \mathrm{~kg} \mathrm{~N} \mathrm{ha}^{-1}$. However, the effect of sowing method and interaction of sowing methods and nitrogen were found significant. Grain weight mainly depends on soil fertility (19), number of tiller and productive tiller [20], and proper nutrients application [21]. Our results are in line with [22] shows that grain weight were significantly improved by nitrogen application.

\section{Biological yield $\left(\mathrm{kg} \mathrm{ha}^{-1}\right)$}

Data regarding biological yield were shown in table 2. High biological yield was recorded in those plots ridge bed sowing method (8549.1) while less amount of biological yield was found in those plots where flat sowing method was done (6889.6). While maximum biological yield (8456.3) was 
obtained at $200 \mathrm{~kg} \mathrm{~N}^{-1}$ followed by $160 \mathrm{~kg}$ $\mathrm{N} \mathrm{ha}{ }^{-1}$ (8021.8). However, the effects of sowing methods and interaction of sowing methods and nitrogen were found significant in which the highest values was recorded in ridge sowing receiving nitrogen rate of 200 $\mathrm{kg} \mathrm{ha}^{-1}$, while the lowest number of tillers per meter square were observed in flat sowing

Table 1. Tiller per meter square and productive tiller of wheat is affected by different level of Nitrogen and sowing methods.

\begin{tabular}{|c|c|c|}
\hline Treatments & Tiller $\mathbf{~ m}^{-2}$ & Productive Tiller \\
\hline Sowing Methods & & $216.55 \mathrm{a}$ \\
\hline Ridge & $256.55 \mathrm{a}$ & $208.40 \mathrm{~b}$ \\
\hline Flat & $238.40 \mathrm{~b}$ & 8.274 \\
\hline LSD $_{0.05}$ & 6.8274 & $215.25 \mathrm{e}$ \\
\hline Nitrogen $\left(\mathrm{kg} \mathrm{N} \mathrm{ha}^{-1}\right)$ & & $220.12 \mathrm{~d}$ \\
\hline 100 & $235.25 \mathrm{e}$ & $216.50 \mathrm{c}$ \\
\hline 120 & $240.12 \mathrm{~d}$ & $203.13 \mathrm{~b}$ \\
\hline 140 & $246.50 \mathrm{c}$ & $242.37 \mathrm{a}$ \\
\hline 160 & $253.13 \mathrm{~b}$ & 4.102 \\
\hline 200 & $262.37 \mathrm{a}$ & $* *$ \\
\hline LSD & 3.202 & $* *$ \\
\hline
\end{tabular}

Mean value of the same category followed by different letters are significant at $\mathrm{P} \leq 0.05$ level

Table 2. Thousand grain weight of wheat is affected by different level of Nitrogen and sowing methods.

\begin{tabular}{|c|c|c|}
\hline Treatments & Thousand grain Weight & Biological yield \\
\hline Sowing Methods & & $8549.1 \mathrm{a}$ \\
\hline Ridge & $46.110 \mathrm{a}$ & $6889.6 \mathrm{~b}$ \\
\hline Flat & $42.185 \mathrm{~b}$ & 161.27 \\
\hline LSD $_{0.05}$ & 4.697 & $7078.4 \mathrm{e}$ \\
\hline Nitrogen $\left(\mathrm{kg} \mathrm{N} \mathrm{ha}^{-1}\right)$ & & $7388.7 \mathrm{~d}$ \\
\hline 100 & $41.700 \mathrm{a}$ & $7651.9 \mathrm{c}$ \\
\hline 120 & $43.700 \mathrm{a}$ & $8021.8 \mathrm{~b}$ \\
\hline 140 & $42.36 \mathrm{a}$ & $8456.3 \mathrm{a}$ \\
\hline 160 & $41.28 \mathrm{~b}$ & 78.436 \\
\hline 200 & $40.18 \mathrm{c}$ & $* *$ \\
\hline LSD
\end{tabular}

Mean value of the same category followed by different letters are significant at $\mathrm{P} \leq 0.05$ level

\section{Grain yield ( $\mathrm{kg} \mathrm{ha}^{-1}$ )}

Data regarding grain yield were shown in table 3. High grain yield (2429.5 $\mathrm{kg} \mathrm{ha}^{-1}$ ) were obtained in those plots where ridge sowing method was done. While less amount of grain yield $\left(2123.2 \mathrm{~kg} \mathrm{ha}^{-1}\right)$ was recorded receiving nitrogen rate of $100 \mathrm{~kg}$ ha ${ }^{-1}$. Biological yield is mainly depending on crop stand [23], root penetration [24] and nitrogen application [25]. Our results are with line [26] who reported that nitrogen increase biological yield. Similarly [27] stated that ridge sowing method increase biological yield. 
effects of sowing methods and interaction of sowing methods and nitrogen were found significant in which the highest values was recorded in ridge sowing receiving nitrogen rate of $120 \mathrm{~kg} \mathrm{ha}^{-1}$, while the lowest number of tillers per meter square were observed in flat sowing receiving nitrogen rate of $100 \mathrm{~kg}$ ha ${ }^{-1}$. Grain yields mainly depend upon on soil organic matter [28], moisture content [29] and nutrient availability [30]. Our results were supported by [31] who stated that ridge bed sowing method significantly increase grain yield. Similarly [32] also stated that nitrogen increase grain yield.

\section{Harvest index (\%)}

Data regarding harvest index were shown in table 3. Highest harvest index (33.50) were obtained in those plots where ridge sowing method was carried out. While lowest

Table 3. Grain yield and harvest index of wheat is affected by different level of Nitrogen and sowing methods.

\begin{tabular}{|c|c|c|}
\hline Treatments & Grain yield & Harvest index \\
\hline Sowing Methods & & $33.550 \mathrm{a}$ \\
\hline Ridge & $2429.5 \mathrm{a}$ & $28.550 \mathrm{~b}$ \\
\hline Flat & $2123.2 \mathrm{~b}$ & 0.842 \\
\hline LSD $_{0.05}$ & 100.16 & $31.37 \mathrm{~b}$ \\
\hline Nitrogen $\left(\mathrm{kg} \mathrm{N} \mathrm{ha}^{-1}\right)$ & & $32.50 \mathrm{a}$ \\
\hline 100 & $2227.1 \mathrm{c}$ & $30.62 \mathrm{c}$ \\
\hline 120 & $2396.9 \mathrm{a}$ & $28.25 \mathrm{~d}$ \\
\hline 140 & $2333.3 \mathrm{~b}$ & $25.75 \mathrm{e}$ \\
\hline 160 & $2258.1 \mathrm{c}$ & 0.7174 \\
\hline 200 & $2166.4 \mathrm{~d}$ & $* *$ \\
\hline LSD & 49.47 & $* *$ \\
\hline
\end{tabular}

Mean value of the same category followed by different letters are significant at $\mathrm{P} \leq 0.05$ level

\section{Conclusion and recommendation}

It was concluded from the study that ridge sowing of wheat increased yield and yield components of wheat as compare to flat sowing. Similarly the application nitrogen at the rate of $120 \mathrm{~kg} \mathrm{ha}^{-1}$ resulted in maximum yield production of wheat. Therefore sowing of wheat on ridges with the application of nitrogen at the rate of $120 \mathrm{~kg} \mathrm{ha}^{-1}$ is amount of harvest index (28.550) was obtained in those plots where flat sowing method was carried out. Similarly maximum number of harvest index (33.50) was obtained at $120 \mathrm{~kg} \mathrm{~N} \mathrm{ha}^{-1}$ while less amount of harvest index was found at the rate of 100 $\mathrm{kg} \mathrm{N} \mathrm{ha-1(31.37).} \mathrm{However} \mathrm{the} \mathrm{effect} \mathrm{of}$ sowing methods and the interaction of sowing method and nitrogen were found significant in which the highest values was recorded in ridge sowing receiving nitrogen rate of $120 \mathrm{~kg} \mathrm{ha}^{-1}$ while the lowest number of tillers per meter square were observed in flat sowing receiving nitrogen rate of $200 \mathrm{~kg}$ ha $^{-1}$. Harvest index of wheat mainly depends upon on biological yield and grain yield. Our results were supported by [32] that nitrogen levels increases harvest index. 


\section{Acknowledgements}

This research work was funded by The University of Swabi. All authors have contributed equally.

\section{References}

1. Tunio, Baraich AAK, Gandahi AWS \& Chachar QD (2006). Influence of micronutrients and their method of application on yield and yield components of sunflower. Pak J Bot 48(5): 1925-1932.

2. Evans LT (1996). Crop evolution, adaptation and yield. Cambridge University Press.

3. Rosegrant MW, Cai X \& Cline SA (2002). World water and food to 2025: dealing with scarcity. Intl Food Policy Res Inst.

4. GOP(2013). Economic Survey Govt. of Pakistan, Finance Division, Economic Advisory Wing, Islamabad, Pakistan.

5. Fahong W, Xuqing W \& Sayre K (2004). Comparison of conventional, flood irrigated, flat planting with furrow irrigated, raised bed planting for winter wheat in China. Field Crops Res 87(1): $35-42$.

6. Dracup M, Belford RK \& Gregory PJ (1992). Constraints to root growth of wheat and lupin crops in duplex soils. Australian J of ExperAgri 32(7): 947-961.

7. Mohtadullah K, Bhutta MN, Wolters W \& Alam MM (1997). Benefits of linking research with design and implementation of drainage projects.

8. Kahlown MA \& Azam M (2002). Individual and combined effect of waterlogging and salinity on crop yields in the Indus basin. Irrigation and Drainage 51(4): 329-338.

9. Ayoub M, Guertin S, Fregeau-Reid J \& Smith DL (1994). Nitrogen fertilizer effect on bread making quality of hard red spring wheat in eastern Canada. Crop Sci 34(5): 1346-1352.
10. Geleto $\mathrm{T}$, Tanner DG, Mamo $\mathrm{T}$ \& Gebeyehu G (1995). Response of rainfed bread and durum wheat to source, level, and timing of nitrogen fertilizer on two Ethiopian vertisols. I. Yield and yield components. Communications in Soil Sci \& Plant Analysis 26(11-12): 17731794.

11. Khan AHMAD, Jan MT, Arif M, Marwat KB \& Jan A (2008). Phenology and crop stand of wheat as affected by nitrogen sources and tillage systems. Pak J of Bot 40(3): 1103-1112.

12. Belford RK, Klepper B \& Rickman RW (1987). Studies of intact shoot-root systems of field-grown winter wheat. II. Root and shoot developmental patterns as related to nitrogen fertilizer. Agronomy J 79(2): 310-319.

13. Yousaf \& Sharif MZ (2014). Stability analysis of cylindrically symmetric selfgravitating systems in $\mathrm{R}+\varepsilon \mathrm{R} 2$ gravity. Monthly Notices of the Royal Astronomical Soc 440(4): 3479-3490.

14. Atlin GN, Lafitte HR, Tao D, Laza M, Amante M \& Courtois B (2006). Developing rice cultivars for highfertility upland systems in the Asian tropics. Field Crops Res 97(1): 43-52.

15. Kalra, Kibe AM \& Singh SN (2006). Water-nitrogen relationships for wheat growth and productivity in late sown conditions. Agri Water Manag 84(3): 221-228.

16. Bouman BAM \& Tuong TP (2001). Field water management to save water and increase its productivity in irrigated lowland rice. AgriWater Manag 49(1): 11-30.

17. Majeed A, Muhmood A, Niaz A, Javid S, Ahmad ZA, Shah SSH \& Shah AH (2015). Bed planting of wheat (Triticum aestivum L.) improves nitrogen use efficiency and grain yield compared to flat planting. The Crop J 3(2): 118-124. 
18. Gopinath KA, Saha S, Mina BL, Pande H, Kundu S \& Gupta HS (2008). Influence of organic amendments on growth, yield and quality of wheat and on soil properties during transition to organic production. Nutrient Cycling in Agroecosyst 82(1): 51-60.

19. Kangas, Peltonen-Sainio PA, Salo Y \& Jauhiainen L (2007). Grain number dominates grain weight in temperate cereal yield determination: Evidence based on 30 years of multi-location trials. Field Crops Res 100(2): 179-188.

20. Spiertz JHJ \& De VNM (1983). Agronomical and physiological aspects of the role of nitrogen in yield formation of cereals. Plant and Soil 75(3): 379391.

21. Simmons SR (1987). Growth, development, and physiology. Wheat and wheat improvement, (wheat and wheatim) 77-113.

22. Palta FM, Bramley HJA \& Siddique KH (2011). Heat stress in wheat during reproductive and grain-filling phases. Critical Rev in Plant Sci 30(6): 491-507.

23. Raun WR, Solie JB, Johnson GV, Stone ML, Mullen RW, Freeman KW \& Lukina EV (2002). Improving nitrogen use efficiency in cereal grain production with optical sensing and variable rate application. Agronomy J 94(4): 815-820.

24. Hussain F, Hojjati M, Okamoto M \& Gorga RE (2006). Polymer-matrix nanocomposites, processing, manufacturing, and application: an overview. J of Composite Materials 40(17): 1511-1575.

25. Soomro UA, Rahman MU, Odhano EA, GulS \& Tareen AQ (2009). Effects of sowing method and seed rate on growth and yield of wheat (Triticum aestivum). World J of Agri Sci 5(2): 159162.

26. Allmaras, Rasmussen PE, Rohde RR \& Roager NC (1980). Crop residue influences on soil carbon and nitrogen in a wheat-fallow system. Soil SciSoc of America J 44(3): 596-600.

27. French RJ \& Schultz JE (1984). Water use efficiency of wheat in a Mediterranean-type environment. I. The relation between yield, water use and climate. Australian J of AgriRes 35(6): 743-764.

28. Coventry DR, Gupta RK, Yadav A, Poswal RS, Chhokar RS, Sharma RK \& Kleemann SGL (2011). Wheat quality and productivity as affected by varieties and sowing time in Haryana, India. Field Crops Res 123(3): 214-225.

29. Zhao S, Qiu S, Cao C, Zheng C, Zhou W \& He P (2014). Responses of soil properties, microbial community and crop yields to various rates of nitrogen fertilization in a wheat-maize cropping system in north-central China. Agri, Ecosys \& Environ 194: 29-37.

30. Donald CM \& Hamblin J (1976). The biological yield and harvest index of cereals as agronomic and plant breeding criteria. Adv in Agron 28: 361-405.

31. Hussain I, Ali A, Ahmed A, Nasrullah H, Khokhar BD, Iqbal S, Aulakh AM, Khan A, Akhter J, \& Ahmed G (2018). Impact of ridge-furrow planting in Pakistan: empirical evidence from the farmers field. Intern J of Agron 2018: 18.

32. Hassan M, Maqsood M, Wajid SA \& Ranjha AM (2015). Rooting pattern and nitrogen use efficiency in cotton (Gossypium hirsutum L.) under moisture stress conditions. J of Animal \& Plant Sci 25(5): 1429-1440. 